\title{
Domestic Labor Migration for Local Tourism Development: From ISAN to Samui, Southern of Thailand
}

\author{
K. Pongponrat
}

\begin{abstract}
Tourism is addressed as the world's largest industry with an extremely growth. Along with this likely unlimited growth, tourism created various consequences on host destination which increasing concerns on uncontrollable development. This paper focuses on Samui Island, a famous beach destination in the southern of Thailand where tourism is an economic activity that plays a vital role in socio-economic development. This study aimed to explore consequences of domestic labor migration from northeastern part of the country to serve as labor force in tourism sector in Samui. Qualitative research methods including document analysis and in-depth interview were applied to identify circumstances and significant issues of socio-cultural changes dealing with domestic labor migration on host community. Results of the study provide guideline to plan and to manage domestic labor migration for local tourism development.
\end{abstract}

Index Terms - Domestic migration, samui, tourism.

\section{INTRODUCTION}

Regards tourism development, it is a major mechanism to promote economic growth for many countries. However, without considering on impact on environmental and socio-culture, this may turn out to be harmful in sensitive area especially the local community where being as a host of tourism development. Regards Thailand, although tourism has brought Thailand benefits such as higher employment, government revenue, foreign exchange, the economic benefits have brought prosperity mainly to urban communities and entrepreneurs. The rate of economic return to local communities has been low. Normally facilities such as resorts, hotels, and tour companies are mainly belong to investors from urban that take most benefits. Local employment opportunities for local people are very limited with a low payment. Numbers of tourist may overexploit natural resources and have a heavy impact on the environment. Some tourism such as trekking and camping have cause environmental pollution from disposal of human waste, discharge of sewerage effluent into water resources, and littering. This is included the coastal spoiled from the over tourism activities. Moreover, without strict regulations on appropriate land use, high rise of buildings such as hotels, and overwhelming number of tourist, the result is congestion and spoiled much of the local scenery. In addition of growing tourism, it may require more infrastructures, transportation, and other facilities which can cause environmental distortion

Manuscript received May 4, 2014; revised July 10, 2014.

$\mathrm{K}$. Pongponrat is with the College of Innovation, Thammasat University, Thailand (e-mail: kannapap@hotmail.com).
[1]-[8].

Considering on socio-cultural aspects, a decline in participation in rural traditional and cultural practices occurs when foreign visitors with different values, disrupting rural culture invade villages. For example, modern buildings replace traditional houses. Also the agriculture, which was the basic traditional life, is replaced by tourism and become as a secondary income instead. Children may drop out from school to get involve in tourism business in several kinds of low paid jobs. Also there is a high rate of migration from rural to tourist destination is increasing for job opportunity from tourism development. This leads to overcrowded population in the target area and abandon original hometown and tradition way of living. Migration can cause a structure imbalance in the host area of tourist destination which effecting on demographic, infrastructure, resources-used, and social services which may not be sufficient to provide for living condition. Previous studies show that massive of migration mostly go beyond the capacity of local resources in the host destination both physical and social context to response to needs of people, meanwhile, it creates pressures on local people to face a problem of resources insufficiency [8]-[12].

Thailand, one of famous tourist destination, where is situated in the heart of Southeast Asia, focuses on tourism development as major economic development mechanism. There are 64 million people and most of them live in rural area for agricultural practices. Since Thailand launched "Visit Thailand Year" in 1987, the number of foreign tourist visiting Thailand has increased dramatically. A number of positive and interactive factors such as aviation technological progress, telecommunications industries and other have contributed to making 1987-1996 the Golden Decade for Thai Tourism. Tourism growth has created employment opportunities across all tourism and travel-related industry sectors. It has been widespread distribution of income, which affects the Thai's way of life. Tourism plays a major role in the Thai economy and it was particularly important in helping overcome impact of the 1997 economic crisis. Thailand's response to changes in global and regional tourism trends has been impressive. Tourism industry share 6\% of GDP in Thailand which accounting for $10.3 \%$ of national employment rate [13]. Thailand has recognized the importance of international tourist market which tourists arrive in year 2009 for more than 14, 584, 220 people.

This paper addresses on Samui Island or so called Koh Samui, a famous beach destination in the southern of Thailand where tourism is a major economic activity. From decades after tourism is boom in this area, there is a high rate of migration from other part of the country to Koh Samui, 
searching for job opportunity and income generation. This research aims to explore consequences of domestic labor migration from northeastern part, so called ISAN, of the country to serve as labor force in tourism sector in Koh Samui. It is a qualitative research which aiming to identify current situations and issues of socio-cultural changes from domestic labor migration. Results provide basis information and guideline for domestic labor migration planning and management to response on local tourism development.

\section{BACKGROUND OF KOH SAMUI}

Koh Samui is a part of a tropical island group that used to be called "Muu Koh Samui," Now it is officially known as Koh Samui District, Surat Thani province, where is located in the southern of Thailand. It is Thailand's third-largest island, occupying the total areaof 252 sq. $\mathrm{km}(157,273$ rais), and is surrounding by 52 smaller islands. Map 1 below shows the location of Koh Samui. Samui's ancient history can be found from as far afield as India and the ancient Khmer empire of what is now Cambodia. The island was probably originally settled by 1500 years ago by the Malay fishermen. But its existence has first been officially recorded by the Chinese only as late as about $1500 \mathrm{AD}$ in ancient maps from the Ming dynasty according to the immigration of Chinese farmers from Hainan province, southern of China. Until 1940s, Koh Samui was famous for producing the best coconuts in the whole of Thailand which had the largest quantity of available coconuts in the entire country. Farmers could sell them for a good price (between five to six bath each), which made Samui residents wealthy. Tourism was unknown on those days. Due to the long isolation from the rest of the world, the islanders are proud of their island culture and still think of themselves differently from the rest of the country. Koh Samui is different from other islands in the southern of Thailand, and its inhabitants refer to themselves as "chao Samui" (Samui folk), rather than Thais.

In the 1950s, it was very difficult to travel to and from Koh Samui, thus, there was little mobility. Transportation from the Koh Samui was difficult. One had to use the coconut delivery boat and the trip to mainland. The population was under 10,000 mainly consisting of the Marayu people and Chinese. Education was provided by the monks in the temples. There was a tradition that every child born on the island had to study in school in Bangkok. This was especially favored by the local Chinese who valued business and social skills and sought relevant instruction on the mainland. In those days poverty was almost unheard of. It was possible to live well and simply by exchanging locally produced goods. The gap between rich and poor was not pronounced, as it is today. There was no electricity at all in most villages. Only $\mathrm{Na}$ Thon community which was the main town of Koh Samui did have an electricity generator which worked during certain hours of the day until midnight. Water was taken from small local wells. Entertainments were limited to buffalo and cock fighting. A few radios were powered by dry batteries but television did not arrive until 1970s. Population consists mainly of Buddhists with a minority of Moslems. There are 39 villages within 7 sub-districts in Koh Samui and is designated as town municipality with a structure of two main bodies consisting of municipality council and city council to manage and carry out development matters in Koh Samui.

Tourism started when the first western travelers, as a back-packer, fell under Samui's spell in started 1970's. They found a peaceful life of fishing and farming going on much as if had for centuries. Those early visitors told their friends and as word got out, the island began to become more popular. During those periods there was little awareness that tourism could become a lucrative industry of benefit to the local economy. Local people on Koh Samui often had to be persuaded to build accommodation or provide services to cater for western needs. In many instances, bungalows were built as a result of persistent suggestions from the succession of visitors, but when arrivals started increasing with a new ferry, it became obvious that tourism offered extra sources of income to many investors. Nowadays, there is decreasingly of an agrarian lifestyle because of the price of coconuts falling to a tenth of their previous value. Local people started to believe that either they can make a living from tourist-funded occupation or they had to leave to the mainland since land selling could make a good price for tourism business related. In last decades, Koh Samui was a small community, with its major economic coconut production, for which the island was famous for the fishing and agriculture. Primary industry was coconut plantations. Samui is said to grow coconuts per square meter in a greater number than anywhere else in the world. Rubber farming industries were also developed, and harvesting of these crops still takes place in the hills of the island's interior. Since tourism booming in year 1990, it becomes a main income for Koh Samui. Most of business areas related to tourism matters such as tour agency, souvenir shops, restaurants, hotels and resorts, and also general labor working in tourism business related.

Koh Samui has become a major tourist attraction on most itineraries for visitors to Thailand. Tourists statistic of Koh Samui shows there were 898,765 international tourists arrived in 2007 which generated income for 13,216.55 million baht in Koh Samui. For domestic tourists, there were 160,877 domestic tourists visited Koh Samui in 2007 which generated income for $1,000.59$ million baht [14]. Since tourism was rapidly developed, Koh Samui has been changing into western civilization. Koh Samui has been witnessed substantial modernization through various infrastructural improvements, including road and sewage projects, and hotels. The taboo on social behavior like walking together and kissing in public has now become obsolete. Moreover, teenagers could find dubious entertainments at any hour and contribute to our alarming high rate of motorcycle accidents after midnight. Some senior people such as teachers in local community reflected that there is a loss of community and associated values. The temple was once the locus of community activities, but this has been lost because people no longer had time for such activities with the frenetic rush for profit and material gain. Local people complained that the beach was no longer their property and they had to ask permission to non-local proprietors to have access to it. Water shortages, waste management, and pollution seem the inevitable outcome of uncontrolled, profit-driven development that nobody can 
influence effectively. One of major issues that Koh Samui now facing is domestic labor migration which effecting to ways of life of native people both in term of living condition and perceptions.

\section{MigRATION IN TOURISM}

If Migration is widely defined as movement across the boundary of an area [9], [10]. In tourism industry, it represents a form of mobility, circulation, and temporary population movement in time and space [15], [16]. Williams and Hall (2002) addressed that tourism is an essential to the lives of migrants as many forms of migration generate tourism flows in particular through the geographical extension of friendship and kinship networks [10]. Migration is not only one-way leaving an individual's original behind, but also a two-way journey between two sets of homes as a process of journey back to the point of [10], [16]. Normally, migrants often carry parts of their origin with them in the form of food, souvenirs, sounds, and scents when they leave their hometown [8] and place it into their second home naturally and automatically.

Since tourism development required massive labor force from other sectors into tourist destination, there are two distinctive migration flows appear in migration connection mentioned by Williams and Hall (2002) consisting of: a) Production led or labor migration which is generated by the requirement to service tourism activities and can generate flows of both skilled and unskilled labor migrants; and b)Consumption led migration systems which include seasonal migration and second home ownership, permanent migration, and non-tourism led lifestyle migration [10].

Muller et al. (2004) and Larsen et al. (2006) stated that skilled labor migrants engaging in long distance commuting are driven by lifestyle and consumption goals while consumption led migrants look for valued environments for temporary or permanent residence [16], [17]. Soontayatron (2010) mentioned that factors related to labor migration flows include scale of demand for labor and the stage of tourism development [8]. Meanwhile, migrant workers for labor force also play a significant role to generate social impact on the host community appearing as socio-cultural changes as a result. Previous studies emphasized that tourism is one of many sources of change interrupting local people's behavior and lifestyle but they need to deal with this change. Local residents who feel harm from tourism impacts may

However, local residents may not only deal with changes from tourists' behavior but only migrants.

Tourism development comes with economic benefits in exchange for social and environmental impacts created by both tourists and migrant workers who serve as labor force in this industry. Considering socio-cultural changes by tourism development which demand labor, possible changes include issues of language and culture, social organization, process of socialization, ethnicity, social control, structure of community, and even dynamic of local custom and lifestyle [18], [19]. Migration also contribute to the formation and reconstruction of national, local, and ethnic identities [8].

\section{RESEARCH METHOdOLOGY}

This is a qualitative research aiming to identify current situation, consequences, and significant issues of domestic labor migration from Northeastern part to Samui Island in the southern part of Thailand. Research methodologies included document analysis, observation, and in-depth interview. There were 20 key informants with different workforces giving the interviews, addressing to anonymous their name and affiliation. Key informants as target of population of the research were divided into 10 native Samui people and 10 migrant workers. This is to understand similarity and difference of idea, comments, perceptions, and attitude of target population. Collected data from in-depth interview were recorded and transcribed into content form. Content analysis was employed to analyze qualitative data to present results with solid discussion.

\section{FINDINGS AND DISCUSSION}

As tourism development creates a highly tourist-dependent economic activities, it is tempting not only non-local Thai people but also foreigners to move an settle an settle down in Koh Samui for income generating opportunities. Meanwhile, many native Samuis move out from the island after they sell their land to investors. Considering domestic labor migration in Koh Samui, majority of migrants are from northeastern part of Thailand or known as ISAN workers, who migrate to escape from traditional agricultural life and hope to earn more money and better lifestyle in growing tourism development areas. This is supporting by the condition of rapid tourism development in Koh Samui which requires labor for construction and also services providing which native Samuis normally not preferred to work in this kind of manual works. This section will delineate current situation, consequence and significant issues related to domestic labor migration in Koh Samui as follow. Presently, Koh Samui has a total population of 51,117 persons who registered for residency and being local population. However, the local government indicates that there might be almost 100,000-150,000 persons who live Koh Samui with unregistered and being non-local population which is three times the size of local population [20], [21]. This extremely increasing of population caused by tourism development on the island as well as having dramatic changes in massive constructions and facilities to serve tourist. Due to this rapidly tourism development, there is high demand on labor for construction as physical development which not many native Samui people preferred to work on this type of manual work, leading to requirement of migrant workers from other area to move in. Majority of migrant workers area from northeastern region of the country or so called Isan.

Isan is dividing into 20 provinces with total population of $21,305,000$. It is located on the Khorat plteau, bordered by the Mekong River, along with border with Laos, to the north and east by Cambodia. ISAN is the Lao-speaking population of the region, calling themselves Khon Isan or Thai Isan. Agriculture is the main economic income generating activity especially rice production. Unfortunately, production lags behind the rest of the country due to the socio-economic 
condition and the exceptionally hot and dry climate. There are frequently droughts with low fertility of land which leading to a low level of productivity results in low income generating for supporting basis life conditions. Isan remains Thailand's poorest region with an average wage were the lowest in the country at 3,928 THB per month while national average was 6,445 THB. Therefore, mostly of Isan population is in debt situation since they need to survive and feed their family with basis needs.

Consequently, many of Isan people decide to migrate to other part of the country where there are opportunities for income generation for better living condition for oneself and their family. Koh Samui became one of the main target areas where migrant workers from Isan choose for migration since there are high opportunities for jobs in tourism development projects and businesses. From interviews with migrant workers, they mentioned five main reasons to migrate from their hometown to Koh Samui which can be clarified as follows.

\section{A. Escape from Poverty}

Due to low productivity in their hometown, this leading to low income earning for their living which leading to low quality of life with insufficient basic needs to survive. Migrant workers preferred to migrate to the area that they can earn more income just for support their family for basic needs. Koh Samui seems to provide more chance for income generating for Isan people.

\section{B. Greater Life Opportunities}

Living in Isan region with poor, hot and dry climate, and drought condition effected to low quality of life. Migrant workers seek for better living condition in other normal or better climate and environments like in Koh Samui. They are seeking for work to support new lifestyles.

\section{Better Job Opportunitie}

As Koh Samui is a highly tourism development area which require many labors to serve in development projects and businesses, migrant workers see opportunities to get better jobs with better conditions of income and job titled. They are seeking for employment and income to meet family needs with an expectation to earn higher wages.

\section{Establishment of Migration Network}

In Koh Samui, there is establishment of Isan community consisting 3,110 households with Isan population of 8,500. Many of Isan people migrated to Koh Samui to live with their family, relatives, and friends. For example, wife migrated to help husband worked in manual work for construction project. After construction project was finished, wife would apply to work in resort or hotel as housekeeper or gardener to continue earning income.

\section{E. Political Issue}

Koh Samui City Municipality structure required local election to work in administrative function of the organization. Somehow, there is a circumstance of "voice of voting' from migrant workers to support election on oneside. Migrant workers will move to Koh Samui during election period for voting their target candidate. This voting will be traded with registered residency and work license to work in Koh Samui.

As mentioning on Isan community in Koh Samui, there is informal established of Isan club in Koh Samui since 1999. It is a loose functioned organization for ethnic identify and social networking consisting of 150 members. President of the Club was from Isan who got married with native Samui people and run a resort business here. This Club is for social activity as well as a place for consulting with various issues, problems, and needs of Isan migrants. Annually, club members set up social activities to support Samui development such beach cleaning or road cleaning. This is to show Isan's responsibilty to area that they come to earn income.

Majority of migrant workers are from Surin province, Buriram province, Chaiyaphum province, Sakon Nakhon province, and Nakohn Phanom province. They migrated by bus or private van company that have a direct route from Isan to Koh Samui. Main job titled that migrant workers engaged including manual labor for constructions of hotels, resorts, and facilities; wage labor such as waiter, dish washer, gardener, housekeeper, or public motorcycle; street vender or beach vender who are self-employment; and bar girls. Some migrant workers are temporary migration to Koh Samui. They will go back to their hometown during harvest season (November-January) result to lose job when they come back to Koh Samui. Meanwhile, it may creates insufficient of labor in Koh Samui in this season as well as season of long holiday such as Thai New Year.

Considering of living condition of migrant workers in Koh Samui, they stay in Isan community where native Samui viewed as slum caused problem of crowded and congested area with poor sanitation. There are 10 Isan communities in Koh Samui. Isan community is located in-land where are plenty of coconut garden, paddy fields, or hidden downtown. In some area, migrant workers need to pay rental for a land from native Samui to settle their simple house. Isan migrant workers have strong social connection and staying in a group. They mentioned that since they all are far away from their hometown, they need to have a strong network to help and to support each other for various matters. Isan migrant workers are living in slum area with poor condition of sanitation. They are, mostly, practicing poultry around their house with create smell and dirty. Native Samui believed that Isan migrant workers caused number of social problems while also create socio-cultural changes in Koh Samui.

Based on field data collection observation and in-depth interview with both native Samui people and Isan migrant workers, there are some significant issues related to socio-cultural changes in Koh Samui. Social exchange circumstance in local society is occurred more if compare with last decades in Koh Samui since Isan migrant workers experience other cultures more than native Samui by having wider and deeper relationship with foreign tourists. They try to engage with foreign tourists as their customers in different tourism related business especially in entertainment business to make customers feel satisfaction. Then, migrant workers may receive more income earning or even better opportunities of their life if they have deeper relationship such as marriage status with foreign tourists. This also helps 
to improve their quality of life and upgrading their social status.

Besides social exchange, there is acculturation and adaptation of socio-culture as Isan migrant workers set up their own community in Samui to maintain their ethnic identify and such as the way of living, food, language, and their custom while try to adapt themselves to interact with foreign tourists by trying to speak English, dressing in western costume style, or even drinking alcohol and dancing in western styles for please foreign tourists. Social identity is one of significant issue to concern as Isan migrant workers are identified as out-groups of Samui community with lower social status as migrant worker with low education. They are looked down by native people within a mindset that migrant workers work for everything to get money.

Since there are high rate of migration in Koh Samui which leading to socio-cutural change, interviews with native Samui show that they are not happy with crowed people which is three times size of registered population in Koh Samui. This leads to insufficient local resources uses and generate slums around communities. In the old day, Koh Samui is a closed community where people normally know their neighbors and many of them are relatives with strong bonding. Since there are many migrant workers move to live in Koh Samui, there are many strangers around community and it is hardly recognize each other which create loosing of community bonding. Ethical issues were also addressed since there are high rate of crime, prostitution, drug addiction, and drug dealing. Native people think that this increasing rate of ethical issues caused by Isan migrant workers.

On the other hand, Isan migrant workers have different thought and feeling for their living in Koh Samui. Based on interviews with Isan migrant workers, they mentioned that even they receive higher income here but still earning less but spending more because there is high living cost in Koh Samui. Also they need to send money back home for their family. This less income pushes Isan migrant workers into dept condition even they earn more in tourist destination if compare with living in their original hometown. Isan migrant workers feel that they were looked down and discriminate by others especially native people. They think they are second class in society and being not important people to concern. So, they feel difficult to find help or support when they face problems.

\section{CONCLUSION AND RECOMMENDATION}

Based on research findings and discussion, there are significant issues to consider on domestic labor migration. In this paper, socio-cultural change is occurring due to high rate of domestic labor migration to work in tourism development in Koh Samui, a world rank beach destination. There are different thoughts and opinions between native Samui and Isan migrant workers on current situation and circumstance of migrant's life in Koh Samui which also create conflicts among people and changing of way of living. As high level of tourism development requires massive labor to serve in this sector, Isan migrant workers are main target for this labor force to support tourism development with an unavoidable.
Local government, as main authority of local development, and related organizations should take more serious concerns and focus on local development within a situation of migration intensively. Local government should formulate long-term workforce planning to identify demanding of labor force with required skills to serve in tourism development. Controlling and monitoring should be employed consistency to track on number of migrant workers. Capacity building for migrant workers such as sanitation or service skills should be provided for them to improve their knowledge and skill. This will help them to improve their work condition and payment or even upgrading their job title to not only work as manual labor but more on skilled job. Finally, to reduce conflict between native people and migrant workers, there is a need of community involvement activities where native, migrant workers, and other local people have a channel to communicate and to work together as collective action for better understanding of each other as well as to support local tourism development which both of them will receive benefits.

\section{REFERENCES}

[1] T. B. Jamal and D. Getz, "Collaboration theory and community tourism planning," Annals of Tourism Research, vol. 22, no. 1, pp. 205-217, 1995.

[2] P. L. Pearce, G. Moscardo, and G. F. Ross, Tourism Community Relationships, Pergamon, 1996.

[3] L. Aronsson, Sustainable Tourism Development: The Development of Sustainable Tourism, New York: Continuum, 2000.

[4] C. Ashley, D. Roe, and H. Goodwin, Pro-Poor Tourism Strategies: Making Tourism Work for the Poor, Nottingham: Overseas Development Institution, 2001.

[5] W. Jamieson, Defining Urban Tourism Destination Management. Community Tourism Destination Management: Principles and Practices, Canadian Universities Consortium, Urban Environment Management Project, Bangkok: Asian Institute of Technology, 2001.

[6] D. Gursoy and D. G. Rutherford, "Host attitude toward tourism: an improved structural modal," Annual of Tourism Research, vol. 31, no. 3, pp. 495-516, 2004.

[7] A. Matheison and G. Wall, Tourism: Changes, Impacts and Opportunities, Harlow: Pearson Prentice Hall, 2006.

[8] S. Soontayatron, "Socio-cultural changes in Thai beach resorts: a case study of Koh Samui Island, Thailand," Ph.D. Dissertation, Doctor of Philosophy, Bournemouth University. UK, 2010.

[9] P. J. Boyle, K. H. Halfacree, and V. Robinson, Exploring Contemporary Migration, Harlow: Longman, 1998.

[10] A. M. William and C. M. Hall, "Tourism and migration: new relationships between production and consumption," Tourism Geographies, vol. 2, no. 1, pp. 5-27, 2000.

[11] Y. Chalamwong, "Recent trends in migration flows and policies in thailand," TDRI Quarterly Review, vol. 16, no. 2, pp. 10-18, 2001

[12] C. H. Swaim, "programming beauty and the absence of Na Lao: popular Thai TV and identity formation among youth in north Thailand," Geographic Journal, vol. 66, pp. 257-272, 2006.

[13] NESDB. (2009). NESDB Report 2009. Official of the National Economic and Social Development Board. [Online]. Available: http://www.nesdb.go.th

[14] Tourism Authority of Thailand. (2007). Tourist Statistic in Koh Samui. Bangkok, Tourism Authority of Thailand. [Online]. Available: http://www.tourismthialand.org

[15] J. Urry, "Mobility and proximity," Sociology, vol. 26, no. 2, pp. 255-274, 2002.

[16] J. Larsen, J. Urry, and K. W. Axhausen, "Networks and tourism: mobile social life," Annual of Tourism Research, vol. 34, no. 1, pp. 244-262, 2007.

[17] D. K. Muller, C. M. Hall, and D. Keen, "Second home tourism impact, planning and management," in Tourism, Mobility and Second Homes: Between Elite Landscape and Common Ground, C. M. Hall, and D. K. Muller, eds., Clevedon: Channel View Publications, 2004.

[18] V. L. Smith, Hosts and Guests: The Anthropology of Tourism, $2^{\text {nd }} \mathrm{ed}$. Philadelphia: University of Pennsylvania Press, 1989. 
[19] T. H. Eriksen, Small Places, Large Issues: An Introduction to Social and Cultural Anthropology, $2^{\text {nd }}$ ed., London: Pluto, 2001.

[20] E. Badone and S. R. Rpse, Intersecting Journeys: The Anthropology of Pilgrimage and Tourism, Urbana: University of Illinois Press, 2004.

[21] City Council of Koh Samui. (2007). Koh Samui: City Council of Koh Samui. [Online]. Available: http://www.kohsamuicity.org

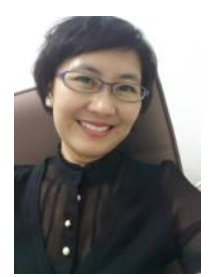

Kannapa Pongponrat received her B.A. in international affair from Thammasat University and her M.A. in development administrative from Western Michigan University. She received Ph.D. in regional and rural development planning from Asian Institute of Technology. She has worked on various issues related to community participatory planning and development for sustainability, sustainable tourism, wastewater management in tourist destination, and resilience for community development. She started her career as researcher with Stockholm Environment Institute-Asia, working on tourism vulnerability analysis for tsunami affected areas in Thailand and Sri Lanka. Subsequently, she served as social experts for projects of EU, CIDA-AIT development projects in Southeast Asia, British Council, Thai government agencies and the private sectors for business and sustainability. Besides working on research, consultancy and regularly teaching,

Dr. Kannapa also gives special talks to publics for issues dealing with sustainable tourism planning and participatory approach for sustainable development. She worked as a full-time lecturer and served as the program director for Master of Management in Tourism and Hospitality Program, International College, Mahidol University. Currently, she works as a full-time lecturer in Service Innovation Program and serves as the associate dean of academic affairs, College of Innovation, Thammasat University.

Dr. Kannapa receives scholarship from Center for Southeast Asian Studies (CSEAS), Kyoto University, Japan for being a visiting researcher in Kyoto during year 2014 under international program of collaborative research of CSEAS. The research topic is comparative study on validity of local tourism for supporting disadvantaged population. Dr. Kannapa focuses on voluntee tourism to support disadvantage population through a case study of tsunami disaster in Japan 2011, to compare with Thailand case of tsunami in 2004 